\title{
Long-term CD4+ lymphocyte response following HAART initiation in a U.S. Military prospective cohort
}

\author{
Alan R Lifson ${ }^{1,8^{*}}$, Elizabeth M Krantz ${ }^{2,8}$, Lynn E Eberly ${ }^{2,8}$, Matthew J Dolan ${ }^{3}$, Vincent C Marconi ${ }^{4}$, Amy C Weintrob ${ }^{5,8}$, \\ Nancy F Crum-Cianflone ${ }^{6,8}$, Anuradha Ganesan ${ }^{7,8}$, Patricia L Grambsch ${ }^{2,8}$, Brian K Agan ${ }^{8}$, \\ for the Infectious Disease Clinical Research Program (IDCRP) HIV Working Group ${ }^{8}$
}

\begin{abstract}
Background: Among HIV-infected persons initiating highly active antiretroviral therapy (HAART), early CD4+ lymphocyte count increases are well described. However, whether CD4+ levels continue to increase or plateau after 4-6 years is controversial.

Methods: To address this question and identify other determinants of CD4+ response, we analyzed data for 1,846 persons from a prospective HIV military cohort study who initiated HAART, who had post-HAART CD4+ measurements, and for whom HIV seroconversion (SC) date was estimated.

Results: CD4+ count at HAART initiation was $\leq 200$ cells $/ \mathrm{mm}^{3}$ for 23\%, 201-349 for 31\%, 350-499 for 27\%, and $\geq 500$ for $19 \%$. The first 6 months post-HAART, the greatest CD4+ increases (93-151 cells) occurred, with lesser increases (22-36 cells/year) through the first four years. Although CD4+ changes for the entire cohort were relatively flat thereafter, HIV viral load (VL) suppressors showed continued increases of 12-16 cells/year. In multivariate analysis adjusting for baseline CD4+ and post-HAART time interval, CD4+ responses were poorer in those with: longer time from HIV SC to HAART start, lower pre-HAART CD4+ nadir, higher pre-HAART VL, and clinical AIDS before HAART $(P<0.05)$.
\end{abstract}

Conclusions: Small but positive long-term increases in CD4+ count in virally suppressed patients were observed. CD4+ response to HAART is influenced by multiple factors including duration of preceding HIV infection, and optimized if treatment is started with virally suppressive therapy as early as possible.

\section{Background}

Among those with human immunodeficiency virus (HIV) infection, the CD4+ T-lymphocyte count is the major indicator of immunodeficiency, a main factor in deciding whether to initiate highly active antiretroviral therapy (HAART), and an important parameter in monitoring treatment response [1,2]. Failure to restore a normal CD4+ count following HAART is associated with increased morbidity due to both AIDS and nonAIDS events, as well as increased mortality [3-5].

\footnotetext{
* Correspondence: lifso001@umn.edu

${ }^{1}$ Division of Epidemiology and Community Health, University of Minnesota, Minneapolis, MN, USA

Full list of author information is available at the end of the article
}

Studies of the kinetics of CD4+ count response postHAART indicate that the CD4+ count increases rapidly during the first 3-6 months, in part due to release of memory $\mathrm{T}$-cells from lymphoid tissue, and then increases slowly during the next 3-4 years, reflecting reconstitution of the immune system [6-10]. The magnitude of CD4+ recovery may depend on a variety of factors, including maintenance of virologic suppression, age, and CD4+ count at HAART initiation [1,7,9,11-20].

The question of whether those initiating HAART will continue to increase their CD4+ count after 4-5 years or will plateau has been debated in the literature, and remains unclear. Some studies have suggested that normalization of CD4+ counts in HIV-infected persons can be achieved if viral suppression with HAART can be

\section{Biomed Central}


maintained for a sufficiently long period of time [19]. In one study, after $>5$ years on HAART, patients with viral suppression who started at $\leq 200$ cells $/ \mathrm{mm}^{3}$ had an adjusted annual increase of 32 cells $/ \mathrm{mm}^{3}$, attaining an average CD $4+$ count of 497 cells $/ \mathrm{mm}^{3}$ [19]. Another study statistically estimating the CD4+ trajectory concluded that those starting HAART at $\leq 200 \mathrm{CD} 4+$ cells who remained on therapy would continue to increase through 7 years, although $25 \%$ still had $\leq 350$ cells at 7 years [20]. One small study of 16 patients followed for up to 10 years with strict viral control based on HIV RNA detection using ultrasensitive techniques showed continued positive increases in CD4+ counts, although this study represented a small group of highly selected patients [21]

On the other hand, other studies report that the average CD4+ count may level off after 4-6 years following HAART initiation, even among patients with viral suppression [12,13]. Given this leveling off, many patients who start at lower CD4+ counts, even after years on HAART with early CD4+ increases, may fail to reach a normal CD4+ threshold. In one study of those with sustained viral suppression who started HAART at $\leq 200$ CD $4+$ cells $/ \mathrm{mm}^{3}$, after 6 years only $42 \%$ had $\geq 500$ CD $4+$ cells $/ \mathrm{mm}^{3}$, and only $12 \%$ had $>750$ cells $/ \mathrm{mm}^{3}$ [12]. In another study, $44 \%$ of those starting therapy with a CD $4+$ count $<100$ cells $/ \mathrm{mm}^{3}$ and $25 \%$ of those starting HAART with a CD4+ count of 100-200 cells were unable to achieve a CD4+ cell count $>500$ cells $/ \mathrm{mm}^{3}$ over a mean follow-up of seven years, and many did not reach this threshold by year 10 [18].

The important question of the long-term CD4+ count response therefore remains unresolved. This question is especially relevant for those who start HAART at lower CD4+ counts. Despite current recommendations to start HAART at CD $4+$ counts of 350 cells $/ \mathrm{mm}^{3}$ or greater $[1,2]$, the reality is that many patients, even in developed countries, are still being diagnosed and initiate treatment late in the course of their HIV infection [22,23].

An additional methodological challenge in using observational data to evaluate the long-term effect of CD4+ count at HAART initiation on subsequent response is that those starting HAART at lower CD4+ levels may have been infected for longer periods of time. If the post-HAART response is affected by duration of HIV infection, comparing different strata without accounting for the fact that those initiating HAART at lower CD4+ levels may have a longer lead-time can result in biased group comparisons [24].

We were able to address both of these issues by analyzing data from the U.S. Military HIV Natural History Study (NHS) [25]. This prospective cohort of HIVinfected U.S. military personnel has followed some participants for up to twelve years after availability of
HAART. Because all active duty personnel are confirmed to be HIV-negative prior to enlistment and undergo routine HIV screening, HIV seroconversion (SC) date can be reliably determined for the majority of members. All cohort members have free access to care and availability of therapy. Data from this cohort were analyzed to determine the long-term CD4+ count trajectory after HAART initiation, as well as the influence of baseline CD4+ count, duration of HIV infection, and other covariates on post-HAART CD4+ response.

\section{Methods}

\section{Study Cohort and Data Elements}

The NHS is an observational prospective cohort study of consenting U.S. military personnel and beneficiaries [25]. Since 1985, routine HIV testing has been used to restrict $\mathrm{HIV}$-infected persons from enlistment. Active duty personnel undergo repeat HIV screening every 1-5 years. Those found HIV-positive after enlistment, plus HIV-positive retirees and dependents of active duty personnel, receive free medical evaluation and ongoing care at military medical centers. Although HIV transmission risk groups are not routinely assessed, injection drug use was not self-reported by any Navy or Marine personnel who seroconverted for HIV during 1997-8 [26]. More recently, hepatitis $\mathrm{C}$ prevalence of only $3 \%$ was reported for evaluable subjects in this cohort [27], consistent with low injection drug use.

Since 1986, the NHS has enrolled 5,091 HIV-positive participants; NHS protocol is for patients to be seen every six months at one of seven participating military medical centers. Data collected include demographics, medical histories including medication use, and laboratory measures including CD4+ count. In 1996, HIV viral load (VL) became available to the study.

This analysis was limited to those with: (1) documented HIV-positive status, (2) HAART receipt after July 1, 1995, with a documented HAART initiation date, (3) a CD4+ count within six months before HAART initiation and (4) at least one follow-up CD4+ count after HAART. Because they represented a distinct population, dependents of active duty personnel were not included in this analysis. Data were evaluated through February 2010.

This substudy was approved by the governing central institutional review board. The study was conducted according to the principles expressed in the Declaration of Helsinki. All study participants in the NHS provided written informed consent

\section{Statistical Analysis}

Of 1846 patients in this analysis, 1475 (80\%) had documented last negative and first positive HIV test dates, with the estimated HIV SC date calculated as the 
mid-point. For 371 (20\%) patients, the date of the first positive but not the last negative HIV test was recorded in the study's database; the estimated SC date for these patients was imputed based upon the median time between the first positive and last negative dates for other cohort members with known and comparable first HIV positive test dates.

Baseline CD4+ count and VL were taken as the values most closely preceding the HAART initiation date within the prior 6 months. For CD4+ response curves, every six-month values were chosen based on the CD4+ count whose date most closely approximated intervals of six month follow-up from HAART initiation; CD4+ counts had to be obtained within a 3 month window of the interval date. $\mathrm{CD} 4+$ follow-up time was truncated at the earliest of the following: last recorded visit at which a CD4+ count was obtained; last recorded visit prior to three successive 6-month visits with missing CD4+ counts; death; or 12-year post-HAART visit.

Visual inspection of the post-HAART CD4+ response curve for all patients indicated that the CD4+ response curves were not simple linear slopes. Based on our inspection, breakpoints of 0.5 and 4.0 years postHAART were assigned, and linear mixed effects models with splines were used to model separate CD4+ slopes for the following time periods after HAART initiation: 0 to 0.5 years; 0.5 to 4 years; and $>4$ years. Random effects for intercepts and slopes were included.

Separate CD4+ response curves were generated for those initiating HAART at CD4+ "baseline" counts of $\leq 200,201-349,350-499$, and $\geq 500$ cells $/ \mathrm{mm}^{3}$. Interactions between post-HAART time period and baseline CD4+ strata were included in linear mixed effects models to estimate and compare separate CD4+ slopes by baseline CD4+ group. Baseline characteristics between CD4+ strata were compared using chi-square tests or analysis of variance.

Unadjusted models first compared CD4+ response trajectories between the four baseline strata; multivariate models then compared baseline CD4+ strata adjusting for the following covariates: age at HAART start, gender, race/ethnicity, presence of clinical AIDS prior to HAART, baseline VL (most closely prior to HAART start), any ART prior to HAART, time from estimated HIV SC date to HAART initiation date, year of HAART start, and nadir pre-HAART CD4+ count. Clinical AIDS was defined as presence of a clinical disease (not CD4+ count) meeting the 1993 Centers for Disease Control AIDS case definition [28]. As previously defined for the NHS [29], HAART included ART regimens with drugs from two or more classes, or certain combinations of three or more nucleoside/nucleotide reverse transcriptase inhibitors (NRTI); patients on ART not meeting the HAART definition were typically on mono or dual
NRTI regimens. Age was modeled as a linear spline to allow for separate linear estimates among those $<40$ years and among those $\geq 40$ years. Holm's stepdown Bonferroni method adjusted for multiple slope comparisons.

This analysis was repeated for the subset of participants defined as VL suppressors. Because VL assays with different detection limits were used during followup, an undetectable VL was defined as $<400$ copies $/ \mathrm{ml}$. VL suppression was defined as two consecutive undetectable VLs, with the first within 48 weeks after HAART start. Data for this subgroup were censored when two consecutive VL measurements $\geq 400$ copies/ $\mathrm{ml}$ were first observed.

To evaluate robustness of our main findings, additional exploratory models were constructed with additional variables added as covariates. In the first model, a timeupdated variable was added to indicate whether the patient was on or off HAART at each 6-month follow-up visit. In the second model, time-updated $\log _{10}$-transformed VL (based on six-month post-HAART values) was added; the separate baseline VL covariate was removed since it is captured in the time-updated covariate. In the third model, initial HAART regimen was added, and categorized as NRTI plus protease inhibitor (PI), NRTIs plus nonnucleoside reverse transcriptase inhibitor (NNRTI), NRTIs alone, and regimens with both NNRTIs and PIs.

\section{Results}

\section{Characteristics at HAART initiation}

One thousand eight hundred and forty-six HIV-positive individuals met analysis inclusion criteria, with characteristics summarized in Table 1 . The median length of follow-up post-HAART was 5.5 years, and median number of CD4+ count values obtained post-HAART (using six-month intervals) was 10 (interquartile range: 4, 18).

CD $4+$ count at HAART initiation was $\leq 200$ cells/ $\mathrm{mm}^{3}$ for $23 \%$ of participants, 201-349 cells for $31 \%$, $350-499$ cells for $27 \%$, and $\geq 500$ cells for $19 \%$. The four strata differed significantly by multiple characteristics (Table 1). Among other differences, AIDS prior to HAART, baseline VL $\geq 100,000$ copies $/ \mathrm{ml}$, and longer time from SC to HAART start were all most common in those with a baseline CD4+ $\leq 200$ cells $/ \mathrm{mm}^{3}$.

\section{CD4+ response curves after HAART initiation}

Figure 1 shows the CD4+ count response after HAART initiation for all participants in this analysis. For the first 6 months after HAART initiation, the average increase in CD4+ count was 129.9 cells (95\% CI 122.0, 137.8). For the second phase (0.5-4.0 years) after HAART, the average annual increase was 29.1 cells (95\% CI 24.5, $33.7)$. For the third phase (4.0-12.0 years), the average annual change was -0.4 cells $(95 \% \mathrm{CI}-4.5,+3.6)$. 
Table 1 Characteristics of Participants in U.S. Military HIV Natural History Study by Baseline CD4+ Strata at HAART Initiation

\begin{tabular}{|c|c|c|c|c|c|}
\hline & \multicolumn{4}{|c|}{ CD4+ (cells $/ \mathrm{mm}^{3}$ ) at HAART start } & \multirow[b]{2}{*}{$\begin{array}{c}\text { Total } \\
(\mathrm{N}=1846) \\
\end{array}$} \\
\hline & $\begin{array}{c}\leq 200 \\
(\mathrm{~N}=419) \\
\end{array}$ & $\begin{array}{r}201-349 \\
(\mathrm{~N}=580) \\
\end{array}$ & $\begin{array}{r}350-499 \\
(\mathrm{~N}=493) \\
\end{array}$ & $\begin{array}{c}\geq 500 \\
(\mathrm{~N}=354) \\
\end{array}$ & \\
\hline Male & $397(95 \%)$ & $566(98 \%)$ & $470(95 \%)$ & $337(95 \%)$ & $1770(96 \%)$ \\
\hline \multicolumn{6}{|l|}{ Race/ethnicity } \\
\hline Caucasian & $169(40 \%)$ & $255(44 \%)$ & $216(44 \%)$ & $172(49 \%)$ & $812(44 \%)$ \\
\hline African American & $199(47 \%)$ & $246(42 \%)$ & $211(43 \%)$ & $139(39 \%)$ & $795(43 \%)$ \\
\hline Hispanic & 38 (9\%) & $54(9 \%)$ & 49 (10\%) & $27(8 \%)$ & $168(9 \%)$ \\
\hline Other & $13(3 \%)$ & $25(4 \%)$ & $17(3 \%)$ & $16(5 \%)$ & $71(4 \%)$ \\
\hline \multicolumn{6}{|l|}{ Year of HAART start * } \\
\hline 1995-1999 & $311(74 \%)$ & $289(50 \%)$ & $298(60 \%)$ & $245(69 \%)$ & $1143(62 \%)$ \\
\hline $2000-2003$ & $43(10 \%)$ & $104(18 \%)$ & 97 (20\%) & $68(19 \%)$ & $312(17 \%)$ \\
\hline 2004-2008 & $65(16 \%)$ & $187(32 \%)$ & $98(20 \%)$ & $41(12 \%)$ & $391(21 \%)$ \\
\hline \multicolumn{6}{|l|}{ Median age at } \\
\hline HAART start $(\mathrm{IQR})$ * & $36(31,42)$ & $34(29,39)$ & $34(28,39)$ & $34(29,39)$ & $34(29,40)$ \\
\hline \multicolumn{6}{|l|}{ CD4+ nadir $\left(\right.$ cells $\left./ \mathrm{mm}^{3}\right) *$} \\
\hline$\leq 200$ & $419(100 \%)$ & $83(15 \%)$ & $20(4 \%)$ & $10(3 \%)$ & $532(29 \%)$ \\
\hline 201-349 & $0(0 \%)$ & $497(86 \%)$ & $180(37 \%)$ & $58(16 \%)$ & $735(40 \%)$ \\
\hline $350-499$ & $0(0 \%)$ & $0(0 \%)$ & $293(59 \%)$ & $96(27 \%)$ & $389(21 \%)$ \\
\hline$\geq 500$ & $0(0 \%)$ & $0(0 \%)$ & $0(0 \%)$ & $190(54 \%)$ & $190(10 \%)$ \\
\hline \multicolumn{6}{|c|}{ Baseline VL at HAART start (copies/ml) * } \\
\hline$<1000$ & $17(4 \%)$ & $37(6 \%)$ & $59(12 \%)$ & $65(18 \%)$ & $178(10 \%)$ \\
\hline $1,000-9,999$ & $25(6 \%)$ & $111(19 \%)$ & 107 (22\%) & $92(26 \%)$ & $335(18 \%)$ \\
\hline 10,000-99,999 & $156(37 \%)$ & $290(50 \%)$ & $231(47 \%)$ & $131(37 \%)$ & $808(44 \%)$ \\
\hline$\geq 100,000$ & $170(41 \%)$ & $117(20 \%)$ & $72(15 \%)$ & $54(15 \%)$ & $413(22 \%)$ \\
\hline Missing & $51(12 \%)$ & $25(4 \%)$ & $24(5 \%)$ & $12(3 \%)$ & $112(6 \%)$ \\
\hline \multicolumn{6}{|l|}{ AIDS diagnosis prior to } \\
\hline HAART * & $116(28 \%)$ & $24(4 \%)$ & $19(4 \%)$ & 7 (2\%) & $166(9 \%)$ \\
\hline On ART prior to HAART * & $277(66 \%)$ & $217(37 \%)$ & $221(45 \%)$ & $146(41 \%)$ & $861(47 \%)$ \\
\hline \multicolumn{6}{|l|}{ Median years HIV SC to } \\
\hline HAART start $(\mathrm{IQR}) *$ & $6.8(3.5,10.1)$ & $3.2(1.3,7.3)$ & $3.3(1.4,7.2)$ & $2.8(1.0,7.2)$ & $4.1(1.4,8.4)$ \\
\hline \multicolumn{6}{|l|}{ Median years post-HAART } \\
\hline follow-up (IQR) ${ }^{* *}$ & $4.9(2.2,11.4)$ & $4.5(2.0,9.2)$ & $6.0(2.1,10.8)$ & $6.1(2.6,10.6)$ & $5.5(2.1,10.5)$ \\
\hline
\end{tabular}

${ }^{*} \mathrm{P}<0.001{ }^{*} \mathrm{P}=0.001$.

HAART = Highly active antiretroviral therapy; ART = Antiretroviral therapy;

$\mathrm{VL}=$ HIV Viral load; IQR = Interquartile range; $\mathrm{SC}=$ Seroconversion.

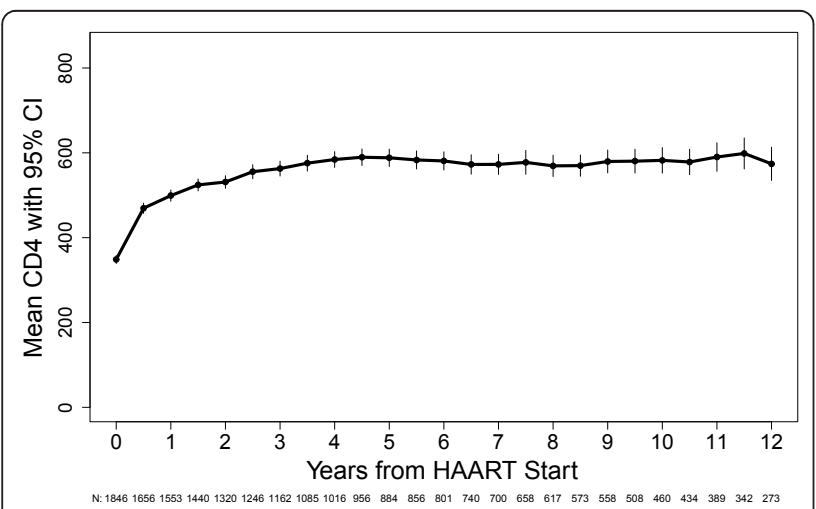

Figure $1 \mathrm{CD} 4+$ Response Curve After HAART Initiation for All Participants, U.S. Military HIV Natural History Study.
Figure 2 shows the $\mathrm{CD} 4+$ count response after HAART initiation by baseline CD4+ stratum. The mean CD4+ cell count at 4,8 , and 12 years post-HAART was 324, 367 and 402 (95\% CI: 356, 448) for the $\leq 200$ CD4+ cell baseline stratum; 532, 513 and 548 (95\% CI: 478, 618) for the 201-349 cell stratum; 641, 611 and 666 (95\% CI: 602, 729) for the 350-499 cell stratum; and 846, 799 and 814 (95\% CI: 684, 945) for the $\geq 500$ cell stratum.

The average CD4+ change and 95\% CI for each of the three post-HAART time intervals are summarized in Table 2; the first time period is presented as CD4+ change per half-year; the second and third time periods present $\mathrm{CD} 4+$ change per year. Within all CD4+ strata, the greatest average increases (93-151 cells) were noted 


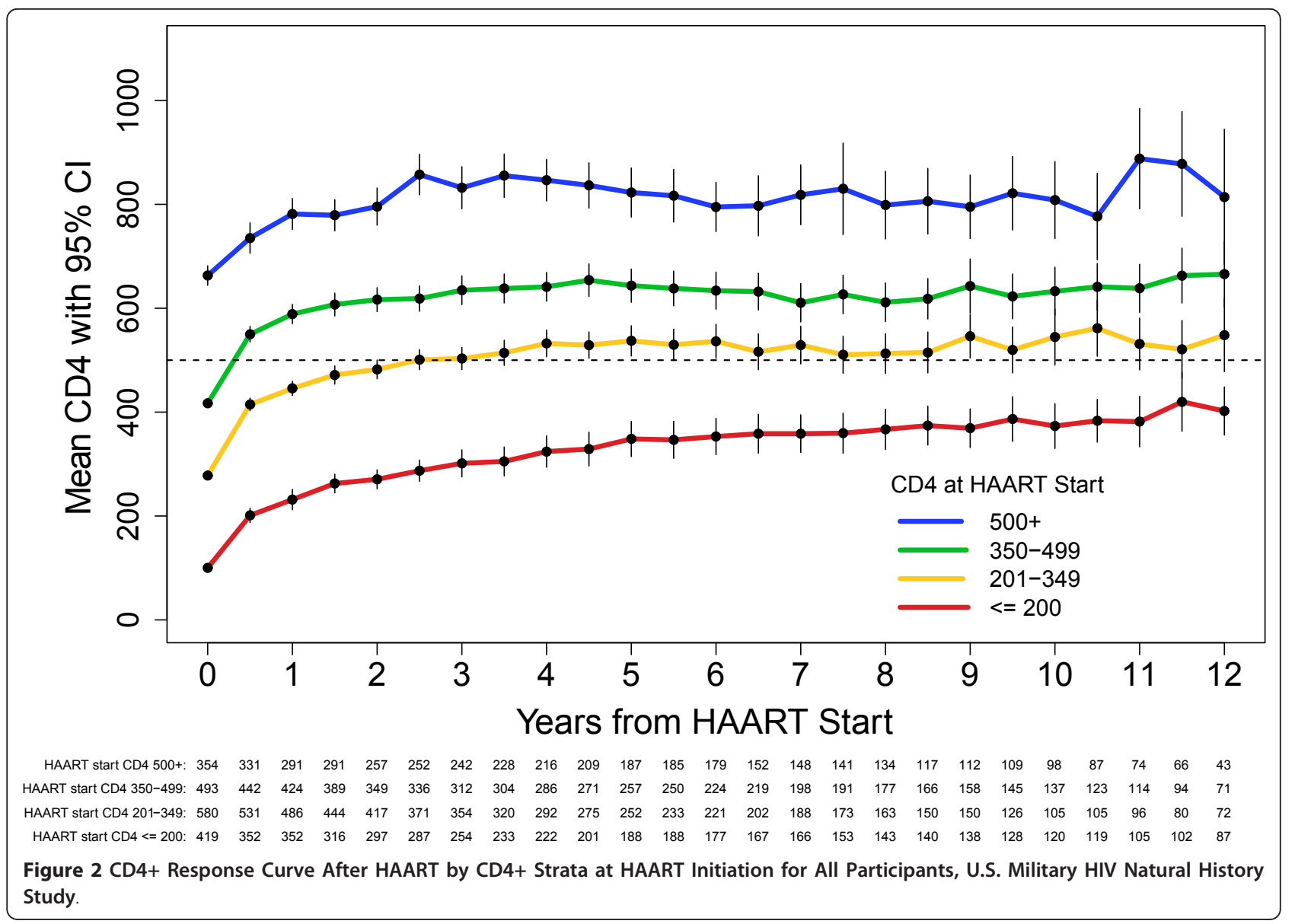

Table 2 Average Change in CD4+ Count by Time Since HAART Initiation: All Participants and Viral Suppressors in U.S. Military HIV Natural History Study

\begin{tabular}{|c|c|c|c|}
\hline \multirow{3}{*}{$\begin{array}{l}\text { CD4+ strata } \\
\text { at HAART start } \\
\end{array}$} & \multicolumn{3}{|c|}{ Estimated CD4+ count change and $95 \% \mathrm{Cl}\left(\mathrm{cells} / \mathrm{mm}^{3}\right)$ by time segment (Years from HAART initiation) } \\
\hline & $\underline{0-0.5 \mathrm{yrs}}$ & $\underline{0.5-4.0 \text { yrs }}$ & $>4.0 \mathrm{yrs}$ \\
\hline & (change/half-year) & (change/year) & (change/year) \\
\hline \multicolumn{4}{|l|}{$\leq 200 \mathrm{cells} / \mathrm{mm}^{3}$} \\
\hline All participants & $109(93,126)$ & $36(30,43)$ & $8.6(3.3,14.0)$ \\
\hline Viral suppressors & $147(123,172)$ & $66(56,75)$ & $13.6(6.0,21.2)$ \\
\hline \multicolumn{4}{|l|}{$201-349$ cells $/ \mathrm{mm}^{3}$} \\
\hline All participants & $149(135,162)$ & $34(28,39)$ & $3.5(-1.3,8.4)$ \\
\hline Viral suppressors & $171(155,188)$ & $54(48,60)$ & $14.4(8.5,20.4)$ \\
\hline \multicolumn{4}{|l|}{ 350-499 cells $/ \mathrm{mm}^{3}$} \\
\hline All participants & $151(136,166)$ & $22(16,28)$ & $1.5(-3.4,6.4)$ \\
\hline Viral suppressors & $177(159,195)$ & $51(44,57)$ & $12.0(6.1,17.8)$ \\
\hline \multicolumn{4}{|l|}{$\geq 500$ cells $/ \mathrm{mm}^{3}$} \\
\hline All participants & $93(75,110)$ & $24(17,30)$ & $-8.1(-13.9,-2.4)$ \\
\hline Viral suppressors & $119(98,139)$ & $56(48,63)$ & $16.2(9.8,22.6)$ \\
\hline
\end{tabular}

* Significant $(P<0.05)$ differences in first-phase slopes: (1) All participants: $\leq 200$ vs. 201-349; <200 vs. 350-499; 201-349 vs. $\geq 500 ; 350-499$ vs. $\geq 500 ;(2)$ VL suppressors: $201-349$ vs. $\geq 500 ; 350-499$ vs. $\geq 500$;

** Significant $(P<0.05)$ differences in second-phase slopes: (1) All participants: $\leq 200$ vs. 350-499; (2) VL suppressors: None;

*** Significant $(P<0.05)$ differences in third-phase slopes: (1) All participants: $\leq 200$ vs. $\geq 500 ; 201-349$ vs. $\geq 500 ; 2)$ VL suppressors: None. (All P-values calculated with multiple comparisons adjustment).

HAART = Highly active antiretroviral therapy; $\mathrm{Cl}=$ Confidence Interval. 
within the first 6 months after HAART initiation. Continued but lesser increases of 22-36 cells/year were noted during the second-phase period of 0.5-4.0 years after HAART initiation. During the third phase $(>4.0$ years post-HAART start), the average CD4+ count increased slightly (9 cells/year) in the lowest baseline $\mathrm{CD} 4+$ stratum, remained essentially unchanged in the two middle baseline strata, and decreased slightly (8 cells/year) in the highest stratum $(\mathrm{P}<0.05)$.

\section{Multivariate analysis and adjusted CD4+ slopes}

In a model controlling for baseline CD4+ count and time interval after HAART start (first-, second- or thirdphase), a number of other variables were significantly $(\mathrm{P}<0.05)$ associated with $\mathrm{CD} 4+$ response (Table 3). A significantly smaller CD4+ response post-HAART occurred in those with clinical AIDS prior to HAART, a lower $\mathrm{CD} 4+$ nadir, a higher baseline $\mathrm{VL}$, a greater number of years from HIV SC to HAART start, Hispanic ethnicity, and HAART initiation during 2000-2003 (vs. 2004-2009). Any ART prior to HAART was of borderline significance $(P=0.07)$.

The numerical estimates listed in Table 3 for different levels of a specific covariate represent what the difference in post-HAART CD4+ counts would be after adjustment for all other covariates in the model. For example, after adjustment for all other covariates, a patient with a baseline VL of $<1000$ copies/ml will on average have a post-HAART CD4+ count that is 57.2 cells higher than a patient with a baseline VL of $\geq$ 100,000 copies/ml (the referent). After adjustment, a patient infected for $>8.5$ years will on average have a post-HAART CD4+ count that is 50.6 cells lower than a patient infected for $\leq 1.5$ years before HAART.

\section{CD4+ response curves for viral suppressors}

One thousand one hundred seventy-one participants met criteria for VL suppressors. Figure 3 shows postHAART CD4+ count responses stratified by CD4+ count at HAART initiation for VL suppressors. The mean CD4+ cell counts at 4,8 , and 12 years postHAART for VL suppressors were 448, 517 and 546 (95\% CI: 405,687$)$ for the $\leq 200$ CD4+ cell baseline stratum; 622, 680 and 737 (95\% CI: 561, 914) for the 201349 CD4+ stratum; 745, 770 and 907 (95\% CI: 791, 1023) for the 350-499 CD4+ stratum; and 947, 1006 and 1075 (95\% CI: 820, 1330) for the $\geq 500 \mathrm{CD} 4+$ cell stratum.

The average CD4+ change and 95\% CI for each of the three post-HAART time intervals for VL suppressors are summarized in Table 2. The greatest changes were again noted within the first 6 months, followed by the $0.5-4.0$ year period. For the third phase ( $>4.0$ years) post-HAART, there were significant annual increase in
Table 3 Adjusted Covariate Estimates * for CD4+ Cell Response Post-HAART for All Participants, U.S. Military HIV Natural History Study

\begin{tabular}{|c|c|c|}
\hline Covariate & $\frac{\text { Estimate }}{(95 \% \mathrm{Cl})}$ & $\frac{P-}{\text { value }}$ \\
\hline \multicolumn{3}{|l|}{ Age at HAART start } \\
\hline $\begin{array}{l}\text { Effect of } 10 \text { years older if }<40 \text { years } \\
\text { old }\end{array}$ & $4.3(-9.3,17.9)$ & 0.54 \\
\hline $\begin{array}{l}\text { Effect of } 10 \text { years older if }>40 \text { years } \\
\text { old }\end{array}$ & $-7.7(-23.3,7.9)$ & 0.34 \\
\hline Female (vs. Male) & $23.0(-8.8,54.8)$ & 0.16 \\
\hline \multicolumn{3}{|l|}{ Race } \\
\hline Caucasian & Reference & \\
\hline African American & $-7.4(-20.5,5.7)$ & 0.27 \\
\hline Hispanic & $-35.0(-57.8,-12.2)$ & 0.003 \\
\hline Other & $-0.7(-35.4,33.9)$ & 0.97 \\
\hline Clinical AIDS event prior to HAART start & $-23.3(-46.1,-0.5)$ & 0.045 \\
\hline \multicolumn{3}{|l|}{ Pre -HAART nadir CD4+ count (cells/mm³) } \\
\hline$\leq 200$ & Reference & \\
\hline 201-349 & $57.2(31.4,83.0)$ & $<.001$ \\
\hline 350-499 & $\begin{array}{l}160.8(129.2 \\
192.5)\end{array}$ & $<.001$ \\
\hline$\geq 500$ & $\begin{array}{l}236.5(196.4 \\
276.6)\end{array}$ & $<.001$ \\
\hline \multicolumn{3}{|l|}{ Baseline VL at HAART start (copies/ml) ** } \\
\hline$<1000$ & $57.2(32.5,81.8)$ & $<.001$ \\
\hline 1000-9999 & $40.2(19.5,60.8)$ & $<.001$ \\
\hline 10,000-99,999 & $14.4(-2.5,31.3)$ & 0.10 \\
\hline$\geq 100,000$ & Reference & \\
\hline \multicolumn{3}{|l|}{ Years from SC to HAART initiation } \\
\hline$\leq 1.5$ & Reference & \\
\hline$>1.5$ to 4.0 & $-28.3(-47.8,-8.8)$ & 0.005 \\
\hline$>4.0$ to 8.5 & $-44.1(-65.3,-23.0)$ & $<.001$ \\
\hline$>8.5$ & $-50.6(-73.4,-27.9)$ & $<.001$ \\
\hline \multicolumn{3}{|l|}{ Year of HAART initiation } \\
\hline 1995-1999 & $-12.8(-36.6,10.9)$ & 0.29 \\
\hline $2000-2003$ & $-34.4(-60.3,-8.4)$ & 0.01 \\
\hline $2004-2009$ & Reference & \\
\hline Any ART prior to HAART start & $-16.4(-34.4,1.6)$ & 0.07 \\
\hline
\end{tabular}

* Aside from baseline CD4+ count and time interval after HAART start. ** Analysis adjusted for those for whom VL was missing/unknown. HAART = Highly active antiretroviral therapy; ART = Antiretroviral therapy; VL = HIV Viral load; $S C=$ Seroconversion;

all baseline strata, although only at a mean of 12-16 cells per year. Second and third phase slopes did not significantly differ for any of the baseline CD4+ strata

\section{Multivariate analysis for VL suppressors}

In multivariate analysis for viral suppressors, factors significantly $(\mathrm{P}<0.05)$ associated with a lesser $\mathrm{CD} 4+$ response include male sex, lower $\mathrm{CD} 4+$ nadir, and greater time from HIV SC to HAART start (Table 4). Clinical AIDS before HAART was of borderline significance $(P=0.057)$. Numerical estimates in Table 4 for 


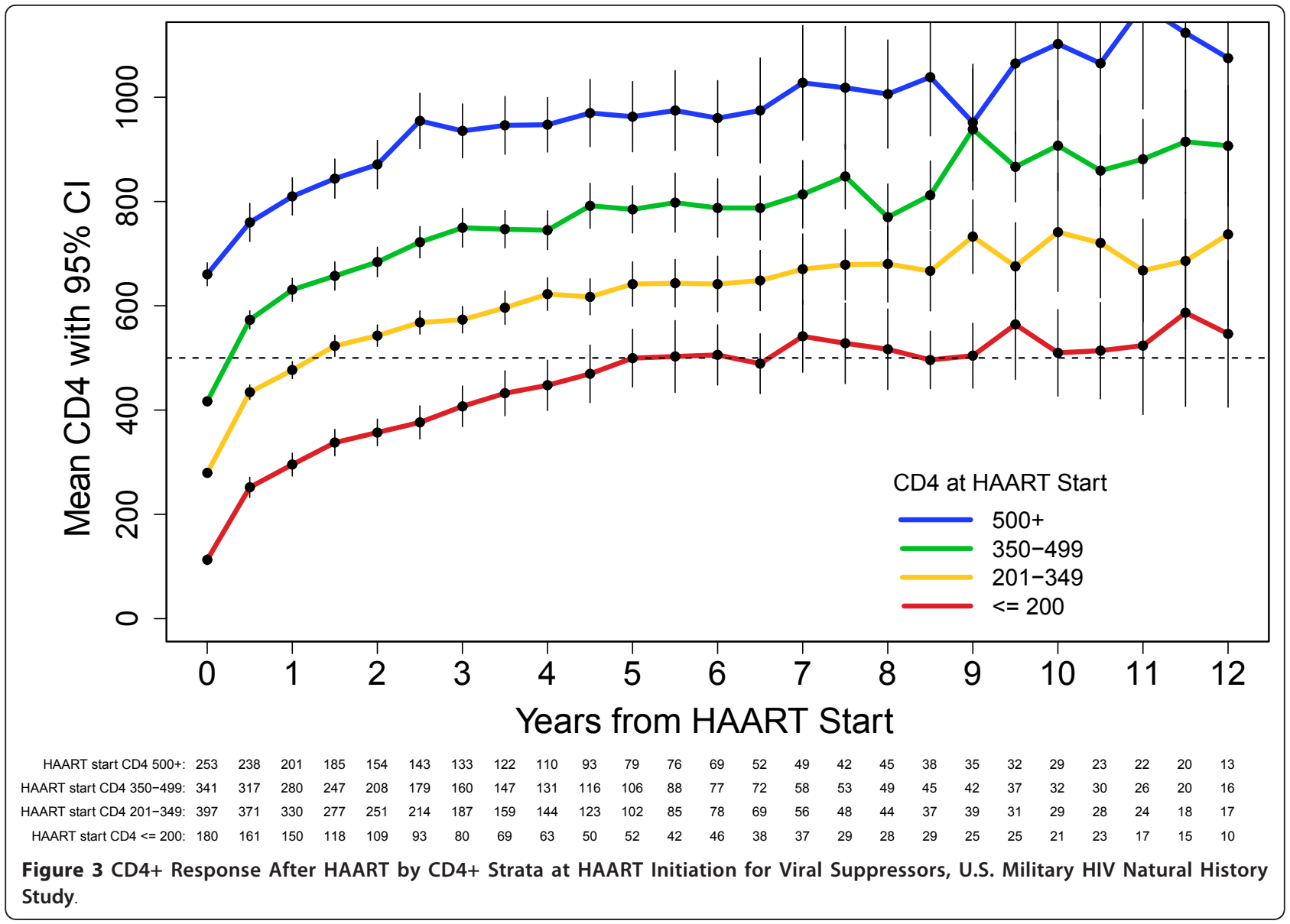

different levels of a specific covariate again represent what the difference in post-HAART CD4+ counts would be after adjustment for all other covariates in the model. For example, after adjustment, a viral suppressor infected for $>8.5$ years will on average have a postHAART CD $4+$ count that is 33.4 cells lower than a patient infected for $\leq 1.5$ years before HAART.

\section{Additional exploratory analyses}

In the first model, the time-updated indicator of HAART use was a significant positive predictor of CD4+ response $($ coefficient $=95.1,95 \%$ CI: 87.8, 102.4, $\mathrm{P}<0.001)$. All significant covariates in the original adjusted model remained so, except for clinical AIDS prior to HAART, which was of borderline significance $(\mathrm{P}=0.055)$. In the second model, time-updated VL after HAART start was a significant predictor of CD4+ response (coefficient $=-42.6$ for every $\log _{10}$ increase in VL, $\mathrm{P}<0.001)$. All significant covariates in the original adjusted model remained so, except for year of HAART initiation. In the third model initial HAART regimen was added to the model. All significant covariates in the original adjusted model remained so.

\section{Discussion}

Among HIV-positive persons starting HAART, we identified a rapid average increase of 93-151 cells during the first six months in all baseline CD4+ strata, followed by a continued average increase of 22-36 cells per year through the first four years. Among VL suppressors, these increases were even greater, with an average of 119-177 cells during the first phase, followed by an average of 51-66 cells per year during the second phase, through 4 years. For example, a patient who starts HAART with a CD4+ count of 125 cells $/ \mathrm{mm}^{3}$ and who maintains viral suppression will on average have an increase to about 500 cells $/ \mathrm{mm}^{3}$ at the end of four years.

A major purpose of this analysis was to identify whether after four years the CD4+ response continues to increase or plateaus. Among all participants, the average third-phase response was slightly positive (8.6 cells/ year) in the lowest CD4+ baseline strata ( $\leq 200$ cells), slightly negative $(-8.1$ cells/year) in the highest strata ( $\geq 500$ cells), and essentially flat (with $95 \% \mathrm{CI}$ overlapping zero) in the two middle strata. However, among VL suppressors, we identified positive average increases 
Table 4 Adjusted Covariate Estimates* for CD4+ Cell Response Post-HAART for Viral Suppressors, U.S. Military HIV Natural History Study

\begin{tabular}{|c|c|c|}
\hline Covariate & $\frac{\text { Estimate }}{(95 \% \mathrm{Cl})}$ & $\frac{P \text { - }}{\text { value }}$ \\
\hline \multicolumn{3}{|l|}{ Age at HAART start } \\
\hline $\begin{array}{l}\text { Effect of } 10 \text { years older if }<40 \text { years } \\
\text { old }\end{array}$ & $6.3(-9.6,22.2)$ & 0.44 \\
\hline $\begin{array}{l}\text { Effect of } 10 \text { years older if }>40 \text { years } \\
\text { old }\end{array}$ & $-5.1(-23.9,13.7)$ & 0.59 \\
\hline Female (vs. Male) & $57.2(14.6,99.8)$ & 0.009 \\
\hline \multicolumn{3}{|l|}{ Race } \\
\hline Caucasian & Reference & \\
\hline African American & $9.2(-7.3,25.7)$ & 0.27 \\
\hline Hispanic & $-10.8(-38.6,17.1)$ & 0.45 \\
\hline Other & $0.4(-40.6,41.4)$ & 0.98 \\
\hline Clinical AIDS event prior to HAART start & $-32.7(-66.4,1.0)$ & 0.057 \\
\hline \multicolumn{3}{|l|}{ Pre -HAART nadir CD4 count (cells $/ \mathrm{mm}^{3}$ ) } \\
\hline$\leq 200$ & Reference & \\
\hline 201-349 & $55.3(20.7,89.9)$ & 0.002 \\
\hline 350-499 & $135.4(94.6,176.2)$ & $<.001$ \\
\hline$\geq 500$ & $\begin{array}{l}195.1(144.3 \\
245.8)\end{array}$ & $<.001$ \\
\hline \multicolumn{3}{|l|}{ Baseline VL at HAART start (copies/ml) ** } \\
\hline$<1000$ & $8.5(-21.6,38.6)$ & 0.58 \\
\hline 1000-9999 & $-17.8(-43.5,7.9)$ & 0.18 \\
\hline 10,000-99,999 & $1.3(-19.5,22.2)$ & 0.90 \\
\hline$\geq 100,000$ & Reference & \\
\hline \multicolumn{3}{|l|}{ Years from SC to HAART initiation } \\
\hline$\leq 1.5$ & Reference & \\
\hline$>1.5$ to 4.0 & $-18.0(-38.6,2.6)$ & 0.09 \\
\hline$>4.0$ to 8.5 & $-27.7(-52.0,-3.3)$ & 0.03 \\
\hline$\geq 8.5$ & $-33.4(-61.0,-5.8)$ & 0.02 \\
\hline \multicolumn{3}{|l|}{ Year of HAART initiation } \\
\hline 1995-1999 & $0.0(-22.4,22.4)$ & 0.99 \\
\hline $2000-2003$ & $5.9(-18.1,29.9)$ & 0.63 \\
\hline $2004-2009$ & Reference & \\
\hline Any ART prior to HAART start & $11.5(-11.1,34.0)$ & 0.32 \\
\hline
\end{tabular}

* Aside from baseline CD4+ count and time interval after HAART start. ** Analysis adjusted for those for whom VL was missing/unknown. HAART = Highly active antiretroviral therapy; ART = Antiretroviral therapy; $\mathrm{VL}=$ HIV Viral load; $\mathrm{SC}=$ Seroconversion;

of approximately 12-16 cells/year, with no significant differences in third-phase slopes between any of the baseline strata. This supports the general conclusion that if viral suppression can be maintained through effective and uninterrupted HAART, a continued pattern of CD4+ count improvement may occur in most patients, irrespective of CD4+ count at HAART initiation.

There are several caveats to this overall conclusion. Although increases four years after starting HAART in viral suppressors continued to be positive, they were small. This provides support for current guidelines to start HAART at higher CD4+ levels, before severe immune suppression has occurred $[1,2,30]$. In addition, our analysis indicates that a variety of other factors may affect and modulate the CD4+ response curve, including nadir CD4+ cell count, AIDS prior to HAART start and pre-HAART duration of HIV infection.

Our analysis is consistent with other studies identifying nadir CD4+ count as a predictor of CD4+ cell response [31,32]. A lower nadir CD4+ count may reflect a more profound disturbance of $\mathrm{T}$-cell homeostasis, with more severe immunological deficits that cannot be reversed even with HAART-induced viral suppression [33]. For example, in one analysis of response to immunization in those with normal CD4+ counts and viral suppression after more than a year, a lower CD4+ nadir before HAART predicted poorer vaccination response [34].

Our analysis also identified a clinical AIDS diagnosis preceding HAART as a predictor of a poorer CD4+ response. This may be another reflection of functional or other immune deficiencies in response to HIV infection that lead to a less robust immunologic recovery. This finding supports current recommendations to initiate HAART in all patients with a history of an AIDSdefining illness, irrespective of their current CD4+ count $[1,2]$.

A major finding of this analysis was the strong negative effect of pre-HAART duration of HIV infection on CD4+ cell response to HAART, even after controlling for viral suppression, CD4+ count and other factors. A previous study [14] also identified duration of infection as a predictor of $\mathrm{CD} 4+$ response, but duration was based upon time from the first recorded HIV test rather than the entire estimated period of HIV infection, as this analysis was able to do. Potential immunopathogenic explanations for why a longer time from HIV SC to HAART start results in a more impaired capacity for immunologic recovery include decreased CD4+ cell production or excessive CD4+ cell destruction. For example, it has been proposed that $\mathrm{CD} 4+\mathrm{T}$-cell hyperactivation may persist even after HAART virologic suppression, and that this results in greater apoptotic cell death [32,33,35-37]. Our finding that both higher baseline VLs and longer duration of pre-HAART infection were predictive of poorer immunologic response suggests that long-standing high levels of viral replication may lead to persistent $\mathrm{T}$-cell activation or other $\mathrm{T}$ cell dysfunction which cannot be fully reversed even after HAART introduction.

This analysis has several potential limitations. First, by definition those who were followed for $>5$ years represent "healthy survivors"; those who died or who dropped out of the study because of illness soon after starting HAART would not be captured in the third-phase 
analysis. Although for the great majority of enrollees death was uncommon, it was more common among those in the lowest $\mathrm{CD} 4+$ cell strata. For example, a preliminary analysis of mortality among those initiating HAART at $\leq 200 \mathrm{CD} 4+$ cells $/ \mathrm{mm}^{3}$ identified a 6 -year death rate of $18 \%$, compared to rates of $3 \%-5 \%$ for those initiating HAART at the higher CD4+ cell strata (IDCRP, unpublished data). Although many patients are still followed in the military health care system even if they are no longer on active duty after an AIDS diagnosis, some patients with advanced disease may have separated from the military system and had their health care transferred to the Veteran's Affairs or other health systems. However, even if such a healthy survivor effect did occur, we do not believe that it significantly affected our overall conclusions. Such an effect would most likely occur in the lowest ( $\leq 200$ cell) CD $4+$ stratum, and among viral suppressors, the third-phase CD4+ increases we saw in this stratum were not significantly different from those seen in the other baseline strata. Nonetheless, the increased mortality seen in the lowest group provides additional support for current guidelines to start HAART before severe immune suppression has occurred.

Second, in this observational study, the four baseline strata were not randomized, and group differences may be due to unmeasured confounding. We tried to limit the extent of confounding by adjusting for many HIVrelated factors, as well as time-dependent covariates including VL and HAART use. Analyzing our data in different ways, including through several different exploratory analyses, did not change our overall conclusions.

Third, although we adjusted for different classes of drug therapy at HAART initiation in our exploratory sensitivity analyses, we did not present data on specific ART drugs. However, this was not the intent of this analysis. Even within a given antiretroviral class, there is considerable variation depending on potency, drug-drug interactions, use of ritonavir boosting for PIs, and multiple other factors. Clinicians may select individual drugs for a HAART regimen based on a variety of factors, and information about the efficacy of specific ART drugs and regimens is best obtained through randomized trials.

Finally, this cohort is characterized by a number of specific demographic and clinical factors, and results may vary for other populations with different characteristics. For example, $96 \%$ of our study sample was male, and the median age was 36 years. Also, given the specific structured testing schedule in the military, it is likely that many patients in this cohort were diagnosed with HIV earlier than typically seen in clinical practice.
This analysis also has several strengths. First, in contrast to many other HIV cohort studies, we were able to estimate SC date and time from HIV SC to HAART start. The fact that this variable consistently emerged as a significant predictor of $\mathrm{CD} 4+$ response supports the importance of including this covariate in our analysis.

Second, follow-up in this analysis extended for some patients out past 8 years, considerably longer than most other observational studies. This analysis therefore provides an important contribution to the literature concerning the long-term third-phase CD4+ response to HAART, especially in those patients who maintain virologic suppression.

Third, because HIV treatment in the military is free, availability of care and access to therapy were not barriers confounding our results. In fact, viral suppression rates in this cohort have previously been reported as approaching those in clinical trials [25].

\section{Conclusions}

Among HIV-infected persons who initiated HAART at different CD4+ levels and who were followed in some cases for over ten years, we identified a rapid followed by a more gradual increase in CD4+ cells for the first four years. After this time, among those who maintain viral suppression, our results suggest that in all strata, there will on average be a positive but small average increase of about 12-16 cells per year. However, multiple factors may influence this immunologic response, including CD4+ nadir, a preceding AIDS diagnosis, and, importantly, time from HIV infection to HAART start. Our findings strongly support the conclusion that immunologic response to HAART is maximized if treatment is started with virally suppressive therapy as early as possible.

\section{Acknowledgements and Funding}

Support for this work (IDCRP-000-03) was provided by the Infectious Disease Clinical Research Program (IDCRP), a Department of Defense program executed through the Uniformed Services University of the Health Sciences, This project has been funded in whole, or in part, with federal funds from the National Institute of Allergy and Infectious Diseases, National Institutes of Health, under Inter-Agency Agreement Y1-Al-5072.

Additional members of the IDCRP HIV/STI Working Group include Susan Banks, Mary Bavaro, Helen Chun, Cathy Decker, Connor Eggleston, Susan Fraser, Joshua Hartzell, Gunther Hsue, Arthur Johnson, Mark Kortepeter, Michael Landrum, Tahaniyat Lalani, Michelle Linfesty, Grace Macalino, Scott Merritt, Robert O'Connell, Jason Okulicz, Shiela Peel, Michael Polis, John Powers, Roseanne Ressner, Edmund Tramont, Tyler Warkentien, Paige Waterman, Timothy Whitman, Ken Wilkins, Glenn Wortmann, and Michael Zapor.

The content and views expressed in this publication is the sole responsibility of the authors and does not necessarily reflect the views or policies of the $\mathrm{NIH}$ or the Department of Health and Human Services, the DoD or the Departments of the Army, Navy, Air Force, Department of Defense, nor the U.S. Government. Mention of trade names, commercial products, or organizations does not imply endorsement by the U.S. Government. 


\section{Author details}

'Division of Epidemiology and Community Health, University of Minnesota, Minneapolis, MN, USA. ${ }^{2}$ Division of Biostatistics, University of Minnesota, Minneapolis, MN, USA. ${ }^{3}$ Defense Institute for Military Operations, Wilford Hall USAF Medical Center, San Antonio, TX, USA. ${ }^{4}$ School of Medicine, Emory University, Atlanta, GA, USA. Infectious Disease, Walter Reed Army Medical Center, Washington, DC, USA. ${ }^{6}$ Infectious Disease, Naval Medical Center-San Diego, San Diego, CA, USA. ${ }^{7}$ Infectious Disease, National Naval Medical Center, Bethesda, MD, USA. Infectious Disease Clinical Research Program, Uniformed Services University of Health Sciences, Bethesda, MD, USA.

\section{Authors' contributions}

AL was lead author on planning and coordinating the analysis, and drafting interim and final versions of the manuscript. EK, PG, and LE conducted and/ or provided guidance with various aspects of the statistical analysis. VM, AW, NC, AG and BA helped to implement the study, including data collection and oversight at the individual study sites at which participants were followed. EK, PG, LE, VM, AW, NC, AG, BA and MD participated in discussions concerning the design of this project, provided feedback and suggestions on interim analyses, and offered valuable input and recommendations on draft versions of this manuscript. All authors have seen and approved the final manuscript.

\section{Competing interests}

The authors declare that they have no competing interests.

Received: 19 October 2010 Accepted: 18 January 2011 Published: 18 January 2011

\section{References}

1. Panel on Antiretroviral Guidelines for Adults and Adolescents: Guidelines for the use of antiretroviral agents in HIV-1-infected adults and adolescents. Dept. Health and Human Services; 2009, 1-161 [http://www. aidsinfo.nih.gov/ContentFiles/AdultandAdolescentGL.pdf].

2. Thompson MA, Aberg JA, Cahn P, Montaner JS, Rizzardini G, Telenti A, Gatell JM, Günthard HF, Hammer SM, Hirsch MS, Jacobsen DM, Reiss P, Richman DD, Volberding PA, Yeni P, Schooley RT: Antiretroviral treatment of adult HIV infection: 2010 recommendations of the International AIDS Society-USA Panel. JAMA 2010, 304:321-33.

3. Baker JV, Peng G, Rapkin J, Krason D, Reilly C, Cavert WP, Abrams Dl, MacArthur RD, Henry K, Neaton JD, Terry Beirn Community Programs for Clinical Research on AIDS (CPCRA): Poor initial CD4+ recovery with antiretroviral therapy prolongs immune depletion and increases risk for AIDS and non-AIDS diseases. J Acquir Immune Defic Syndr 2008, 48:541-6.

4. Study Group on Death Rates at High CD4 Count in Antiretroviral Naive Patients: Death rates in HIV-positive antiretroviral-naive patients with CD4 count greater than 350 cells per $\mu \mathrm{L}$ in Europe and North America: a pooled cohort observational study. Lancet 2010, 376:340-5.

5. Lawn SD, Little F, Bekker LG, Kaplan R, Campbel E, Orrell C, Wood R: Changing mortality risk associated with CD4 cell response to antiretroviral therapy in South Africa. AIDS 2009, 23:335-42.

6. Pakker NG, Notermans DW, de Boer RJ, Roos MT, de Wolf F, Hill A, Leonard JM, Danner SA, Miedema F, Schellekens PT: Biphasic kinetics of peripheral blood T cells after triple combination therapy in HIV-1 infection: a composite of redistribution and proliferation. Nat Med 1998, 4:208-14.

7. Battegay $M$, Nüesch R, Hirschel B, Kaufmann GR: Immunological recovery and antiretroviral therapy in HIV-1 infection. Lancet Infect Dis 2006, 6:280-7.

8. Bucy RP, Hockett RD, Derdeyn CA, Saag MS, Squires K, Sillers M, Mitsuyasu RT, Kilby JM: Initial increase in blood CD4+ lymphocytes after HIV antiretroviral therapy reflects redistribution from lymphoid tissues. $J$ Clin Invest 1999, 103:1391-8.

9. Hunt PW, Deeks SG, Rodriguez B, Valdez H, Shade SB, Abrams DI, Kitahata MM, Krone M, Neilands TB, Brand RJ, Lederman MM, Martin JN: Continued CD4 cell count increases in HIV-infected adults experiencing 4 years of viral suppression on antiretroviral therapy. AIDS 2003, 17:1907-1915.

10. Smith K, Aga E, Bosch RJ, Valdez H, Connick E, Landay A, Kuritzkes D, Gross BH, Francis IR, McCune JM, Kessler H, Lederman M: Long-term changes in circulating CD4 T lymphocytes in virologically suppressed patients after 6 years of highly active antiretroviral therapy. AIDS 2004, 18:1953-6.

11. Landay A, da Silva BA, King MS, Albrecht M, Benson C, Eron J, Glesby M, Gulick R, Hicks C, Kessler H, Murphy R, Thompson M, White AC Jr, Wolfe P, McMillan Fl, Hanna GJ: Evidence of ongoing immune reconstitution in subjects with sustained viral suppression following 6 years of lopinavirritonavir treatment. Clin Infect Dis 2007, 44:749-54.

12. Moore RD, Keruly JC: CD4+ cell count 6 years after commencement of highly active antiretroviral therapy in persons with sustained virologic suppression. Clin Infect Dis 2007, 44:441-6.

13. Gras L, Kesselring AM, Griffin JT, van Sighem Al, Fraser C, Ghani AC, Miedema F, Reiss P, Lange JM, de Wolf F, ATHENA, Netherlands National Observational Cohort Study: CD4 cell counts of 800 cells $/ \mathrm{mm}^{3}$ or greater after 7 years of highly active antiretroviral therapy are feasible in most patients starting with 350 cells $/ \mathrm{mm}^{3}$ or greater. J Acquir Immune Defic Syndr 2007, 45:183-92.

14. Kaufmann GR, Furrer $H$, Ledergerber $B$, Perrin L, Opravil M, Vernazza $P$, Cavassini M, Bernasconi E, Rickenbach M, Hirschel B, Battegay M, Swiss HIV Cohort Study: Characteristics, determinants, and clinical relevance of CD4 T cell recovery to $<500$ cells/ $\mu \mathrm{L}$ in HIV type 1 -infected individuals receiving potent antiretroviral therapy. Clin Infect Dis 2005, 41:361-72.

15. Khanna N, Opravil M, Furrer H, Cavassini M, Vernazza P, Bernasconi E, Weber R, Hirschel B, Battegay M, Kaufmann GR, Swiss HIV Cohort Study: CD4+ T cell count recovery in HIV type 1-infected patients is independent of class of antiretroviral therapy. Clin Infect Dis 2008, 47:1093-101

16. Nash D, Katyal M, Brinkhof MW, Keiser O, May M, Hughes R, Dabis F, Wood R, Sprinz E, Schechter M, Egger M, ART-LINC Collaboration of leDEA: Long-term immunologic response to antiretroviral therapy in lowincome countries: a collaborative analysis of prospective studies. AIDS 2008, 22:2291-302

17. García F, de Lazzari E, Plana M, Castro P, Mestre G, Nomdedeu M, Fumero E, Martínez E, Mallolas J, Blanco JL, Miró JM, Pumarola T, Gallart T, Gatell JM: Long-term CD4+ T-cell response to highly active antiretroviral therapy according to baseline CD4+ T-cell count. J Acquir Immune Defic Syndr 2004, 36:702-13.

18. Kelley CF, Kitchen CM, Hunt PW, Rodriguez B, Hecht FM, Kitahata M, Crane HM, Willig J, Mugavero M, Saag M, Martin JN, Deeks SG: Incomplete peripheral CD4+ cell count restoration in HIV-infected patients receiving long-term antiretroviral treatment. Clin Infect Dis 2009, 48:787-94.

19. Mocroft A, Phillips AN, Gatell J, Ledergerber B, Fisher M, Clumeck N, Losso M, Lazzarin A, Fatkenheuer G, Lundgren JD, EuroSIDA study group: Normalisation of CD4 counts in patients with HIV-1 infection and maximum virological suppression who are taking combination antiretroviral therapy: an observational cohort study. Lancet 2007 . 370:407-13.

20. Lok JJ, Bosch RJ, Benson CA, Collier AC, Robbins GK, Shafer RW, Hughes MD, ALLRT team: Long-term increase in CD4+ T-cell counts during combination antiretroviral therapy for HIV-1 infection. AIDS 2010, 24:1867-76.

21. Guihot A, Tubiana R, Breton G, Marcelin AG, Samri A, Assoumou L, Goncalves E, Bricaire F, Costagliola D, Calvez V, Rouzioux C, Autran B, Katlama C, Carcelain G, ALT-ANRS CO-15 study group, DECAMUNE study group: Immune and virological benefits of 10 years of permanent viral control with antiretroviral therapy. AIDS 2010, 24:614-17.

22. Althoff KN, Gange SJ, Klein MB, Brooks JT, Hogg RS, Bosch RJ, Horberg MA, Saag MS, Kitahata MM, Justice AC, Gebo KA, Eron JJ, Rourke SB, Gill MJ, Rodriguez B, Sterling TR, Calzavara LM, Deeks SG, Martin JN, Rachlis AR, Napravnik S, Jacobson LP, Kirk GD, Collier AC, Benson CA, Silverberg MJ, Kushel M, Goedert JJ, McKaig RG, Van Rompaey SE, Zhang J, Moore RD, North American AIDS Cohort Collaboration on Research and Design: Late presentation for human immunodeficiency virus care in the United States and Canada. Clin Infect Dis 2010, 50:1512-20.

23. Keruly JC, Moore RD: Immune status at presentation to care did not improve among antiretroviral-naive persons from 1990 to 2006. Clin Infect Dis 2007, 45:1369-74.

24. Cole SR, Li R, Anastos K, Detels R, Young M, Chmiel JS, Muñoz A: Accounting for leadtime in cohort studies: evaluating when to initiate HIV therapies. Stat Med 2004, 23:3351-63.

25. Marconi VC, Grandits GA, Weintrob AC, Chun H, Landrum ML, Ganesan A, Okulicz JF, Crum-Cianflone N, O'Connell RJ, Lifson A, Wortmann GW, 
Agan BK, the Infectious Disease Clinical Research Program HIV Working Group (IDCRP): Outcomes of highly active antiretroviral therapy in the context of universal access to healthcare: the U.S. Military HIV Natural History Study. AIDS Res Ther 2010, 7:14.

26. Brodine SK, Shaffer RA, Starkey MJ, Tasker SA, Gilcrest JL, Louder MK, Barile A, VanCott TC, Vahey MT, McCutchan FE, Birx DL, Richman DD, Mascola JR: Drug resistance patterns, genetic subtypes, clinical features, and risk factors in military personnel with HIV-1 seroconversion. Ann Intern Med 1999, 131:502-6.

27. Chun HM, Fieberg AM, Huppler Hullsiek K, Lifson AR, Crum-Cianflone NF, Weintrob AC, Ganesan A, Barthel RV, Bradley WP, Agan BK, Landrum ML, Infectious Disease Clinical Research Program HIV Working Group: Epidemiology of Hepatitis B virus infection in a US cohort of HIVinfected individuals during the past 20 years. Clin Infect Dis 2010, 50:426-36.

28. Centers for Disease Control: 1993 revised classification system for HIV infection and expanded surveillance case definition for AIDS among adolescents and adults. MMWR 1992, 41(RR-17):1-19.

29. Weintrob AC, Grandits GA, Agan BK, Ganesan A, Landrum ML, CrumCianflone NF, Johnson EN, Ordóñez CE, Wortmann GW, Marconi VC, IDCRP HIV Working Group: Virologic response differences between African Americans and European Americans initiating highly active antiretroviral therapy with equal access to care. J Acquir Immune Defic Syndr 2009, 52:574-580.

30. World Health Organization: Rapid advice: antiretroviral therapy for HIV infection in adults and adolescents, November 2009. Geneva: WHO; 2009, 1-24 [http://www.who.int/hiv/pub/arv/rapid_advice_art.pdf].

31. McKinnon LR, Kimani M, Wachihi C, Nagelkerke NJ, Muriuki FK, Kariri A, Lester RT, Gelmon L, Ball TB, Plummer FA, Kaul R, Kimani J: Effect of baseline HIV disease parameters on CD4+ T cell recovery after antiretroviral therapy initiation in Kenyan women. PLoS One 2010, 5 : e11434.

32. Negredo E, Massanella M, Puig J, Pérez-Alvarez N, Gallego-Escuredo JM, Villarroya J, Villarroya F, Moltó J, Santos JR, Clotet B, Blanco J: Nadir CD4 T cell count as predictor and high CD4 T cell intrinsic apoptosis as final mechanism of poor CD4 T cell recovery in virologically suppressed HIVinfected patients: clinical implications. Clin Infect Dis 2010, 50:1300-8.

33. Gazzola L, Tincati C, Bellistrì GM, Monforte A, Marchetti G: The absence of CD4+ T cell count recovery despite receipt of virologically suppressive highly active antiretroviral therapy: clinical risk, immunological gaps, and therapeutic options. Clin Infect Dis 2009, 48:328-37.

34. Lange CG, Lederman MM, Medvik K, Asaad R, Wild M, Kalayjian R, Valdez H: Nadir CD4+ T-cell count and numbers of CD28+ CD4+ T-cells predict functional responses to immunizations in chronic HIV-1 infection. AIDS 2003, 17:2015-23.

35. Valdez H, Connick E, Smith KY, Lederman MM, Bosch RJ, Kim RS, St Clair M, Kuritzkes DR, Kessler H, Fox L, Blanchard-Vargas M, Landay A, AIDS Clinical. Trials Group Protocol 375 Team: Limited immune restoration after 3 years' suppression of HIV-1 replication in patients with moderately advanced disease. AIDS 2002, 16:1859-66.

36. Pitrak DL, Bolaños J, Hershow R, Novak RM: Discordant CD4 T lymphocyte responses to antiretroviral therapy for HIV infection are associated with ex-vivo rates of apoptosis. AIDS 2001, 15:1317-9.

37. Hunt PW, Martin JN, Sinclair E, Bredt B, Hagos E, Lampiris H, Deeks SG: T cell activation is associated with lower CD4+ T cell gains in human immunodeficiency virus-infected patients with sustained viral suppression during antiretroviral therapy. J Infect Dis 2003, 187:1534-43.

doi:10.1186/1742-6405-8-2

Cite this article as: Lifson et al: Long-term CD4+ lymphocyte response following HAART initiation in a U.S. Military prospective cohort. AIDS

Research and Therapy 2011 8:2.

\section{Submit your next manuscript to BioMed Central and take full advantage of:}

- Convenient online submission

- Thorough peer review

- No space constraints or color figure charges

- Immediate publication on acceptance

- Inclusion in PubMed, CAS, Scopus and Google Scholar

- Research which is freely available for redistribution

Submit your manuscript at www.biomedcentral.com/submit
Biomed Central 